\title{
BIHARI PÉTER
}

\section{A jegybanki függetlenség és elszámoltathatóság a válság előtt és után}

\begin{abstract}
A válságot megelőzően a jegybankok müködési kereteit meghatározó formális szabályok biztosították a monetáris politikai célok eléréséhez szüikséges magas fokú jegybanki autonómiát. A tényleges függetlenség azonban a döntéshozók kinevezése és felmentése során érvényesülő politikai szempontok következtében már ekkor sem érvényesült teljes egészében. A válság hatására felértékelődött a makroprudenciális politika, ami új feladatokat jelent a jegybankok számára. A jegybanki függetlenség válság előtti értelmezése a megváltozott makrogazdasági körülmények és a kibővült jegybanki tevékenység fényében felülvizsgálatra szorul. Az árstabilitás továbbra is csak a jegybanki eszközök politikai befolyástól mentes használata mellett teremthető meg. A makroprudenciális tevékenység azonban csak a kormányzattal együttmüködésben végezhető, ami megnehezíti a klasszikus monetáris politika autonómiájának fenntartását. De facto várhatóan tovább szükül a jegybank függetlensége a kamatpolitika területén is, aminek negatív társadalmi következményei majd akkor válnak láthatóvá, amikor az árstabilitás érdekében szigorítani kell a monetáris politikán, ám a rövid távú politikusi érdekektől esetleg eltérő döntések meghozatalához nem lesz a jegybanknak ereje.

Journal of Economic Literature (JEL) kód: H11, G18, E42, E52, E58, G18, H68.
\end{abstract}

Nagyon kevés olyan szakmai-tudományos vita van, amelyik az egyik oldal teljes és végérvényes győzelmével zárul. A jegybanki függetlenségről folyó párbeszéd bizonyosan nem ilyen. Az intézményi berendezkedéssel kapcsolatos viták a nyolcvanas években, a rögzített árfolyamrendszerről való letérés és egy új monetáris politikai rendszerrel kapcsolatos útkeresés idején kezdődtek, és nagyjából a 2000-es évek elejére nyugvópontra jutottak. Maradtak ellenvélemények, de a leginkább elfogadott nézet szerint a jegybank politikai befolyástól mentes müködése szükséges feltétel a monetáris politikai célok teljesüléséhez. A válságot követően a megváltozott makrogazdasági körülmények között a függetlenség melletti régi érvek új megvilágításba kerültek, új szempontok merültek fel, amelyek a függetlenség tartalmának, határainak újragondolására késztetnek. A korábbi konszenzus felborult, az elvi szakmai vita újraéledt. Jelen írás ehhez a vitához kapcsolódva tekinti

Bihari Péter a Budapesti Gazdasági Egyetem tudományos főmunkatársa, a Budapesti Corvinus Egyetem egyetemi docense.

A kézirat első változata 2017. április 23-án érkezett szerkesztőségünkbe.

DOI: http://dx.doi.org/10.18414/KSZ.2017.6.573 
át a függetlenség melletti hagyományos érvrendszert, és tesz kísérletet ezek újrafogalmazására a megváltozott körülmények figyelembevételével. Előrebocsátva a cikk végkövetkeztetését: de jure a fejlett országok jegybankjai magas szintü függetlenséget értek el az ezredfordulóra, a de facto jegybanki függetlenség azonban kisebb volt annál, mint amit a különböző mérési indexek mutattak. A válság utáni időszakban a kamatpolitika területén változatlanul szükséges a rövid távú politikai érdekek befolyásától való mentesség, miközben a pénzügyi stabilitás - mint a későbbiekben látni fogjuk - csak a jegybank és kormány szoros együttmüködésében őrizhető meg. Ez a kettősség nagy valószínűséggel ahhoz vezet, hogy a de facto jegybanki függetlenség a monetáris politika területén csorbát szenved, és alacsonyabb szinten állandósul, mint a válság elötti időszakban.

A cikk újszerüségét az adja, hogy a közgazdasági megközelítést több helyen ötvözi politikai gazdaságtani megfontolásokkal. Ez elsősorban a de facto és de jure jegybanki függetlenség megkülönböztetése terén szolgál új eredményekkel. Jelen írás nem konkrét országok eseteit tárgyalja, hanem - az általánosítás kockázatait vállalva - a jegybanki függetlenségnek azokat a közös vonásait igyekszik megragadni, amelyek a legtöbb jegybankra érvényesek. Bár a magyar tapasztalatokat nem emeli ki külön az írás, de több olyan következtetést is tartalmaz, amelyek hazai szempontból különleges jelentőségüek.

A tanulmány elöször a függetlenséget megalapozó elvi szempontokat tekinti át úgy, ahogy azok a válság előtti időben felmerültek, majd a jegybanki függetlenséggel kapcsolatos empirikus tényeket foglalja össze. Ezt követően azt vizsgálja, hogy a függetlenség melletti eredeti érvek megállják-e helyüket a mai viszonyok között, és a jegybankok kibővült feladatköre, elsősorban a pénzügyi stabilitási feladatok milyen mértékű együttműködést igényelnek a kormányzati politika formálói részéröl. A cikk következtetések levonásával zárul.

\section{Közgazdasági és politikai gazdaságtani érvek a jegybanki függetlenség mellett - a válság előtt}

A 20. század utolsó negyedének egyik alapvető makrogazdasági problémája a megnövekedett infláció volt, ami több országban is alacsony növekedési ütemmel párosult. Kiderült, hogy nem érvényesül a Philips-görbe. Mind a gazdaságpolitika, mind a közgazdasági elmélet kereste a tartósan alacsony infláció elérésének lehetöségeit és a legjobb intézményi megoldásokat. A 2000 -es évek elejére gyakorlatilag konszenzus alakult ki arról, hogy a monetáris politika az árstabilitás fenntartásával járulhat leginkább hozzá a gazdasági növekedéshez, az árstabilitás elérését pedig a jegybank politikai befolyástól mentes müködése biztosíthatja. A konszenzus elméleti kiindulópontját elsősorban Rogoff [1985], Debelle-Fischer [1994], Sargent-Wallace [1981], Kydland-Prescott [1977] munkái jelentették. A letisztult végeredmény azonban - felsorolhatatlanul - sokak közös müve. A következőkben a jegybanki függetlenség melletti három legfontosabb érvet elevenítem fel. ${ }^{1}$

\footnotetext{
${ }^{1}$ Tekintettel arra, hogy az alábbi három pont a nemzetközi irodalomban nagyjából általánosan elfogadott érveket foglalja össze, a szerzői hivatkozásoktól eltekinthetünk.
} 
1. Az árstabilitás szintjénél magasabb infláció a pénztartás és a gazdálkodás költségeinek növelése, a jövedelem-újraelosztás torzító szerepe, valamint a jövőbeli folyamatok romló kiszámíthatósága következtében a potenciálistól elmaradó növekedésre vezet, és egyben a potenciális növekedés mértékére is kedvezőtlenül hat. ${ }^{2}$ A politikusok az irántuk megnyilvánuló közbizalom erősítése, hatalomban maradásuk esélyeinek növelése érdekében akkor is hajlamosak adómérséklésekre, új jóléti kiadások, új közberuházások indítására, ha az ezen intézkedések révén keletkező jóléti többlet növeli az inflációt. Abban bíznak, hogy a növekedési hatások jelentkeznek előbb, az árak pedig csak késleltetve - lehetőleg a következő választásokat követően - és csak átmenetileg emelkednek. ${ }^{3}$

A keresleti sokk hatására azonban a gazdasági növekedés csak átmenetileg emelkedik, az inflációs következmények viszont tartósak maradhatnak. Mivel az árstabilitással kapcsolatos hosszú távú érdekek nincsenek összhangban a rövid távú politikusi érdekekkel, indokolt az árstabilitás ügyét a kormányzati struktúrán kívüli intézmény felelősségévé tenni. Ez az intézmény a jegybank. A jegybank is csak akkor képes az árstabilitás elérésére, ha nemcsak formális értelemben kerül a kormányzati struktúrán kívülre, hanem tényleges tevékenysége mentesül a rövid távú politikai érdekek befolyásától. ${ }^{4}$

Számos empirikus tanulmány született, amely korrelációt mutatott ki a jegybanki függetlenség és az alacsony infláció, illetve a függetlenség hiánya és a magas infláció között (Alesina [1988], Cukierman [1992], Grilli és szerzőtársai [1991], Arnone-Romelli [2013]). És olyan tanulmányok is születtek, amelyek a kettő között ok-okozati kapcsolatot állapítottak meg (Masciandaro-Romelli [2017]). Sőt Cukierman és szerzötársai [1992] szerint a sikeres antiinflációs monetáris politika a jegybank iránti közbizalom erösítésén keresztül hozzájárulhat a függetlenség megerösítéséhez is. ${ }^{5}$

A jegybanki függetlenség azonban nem garancia az árstabilitás megvalósulására. Ha nincs támogató társadalmi környezet, ha a gazdaságpolitika maga is inflációt gerjeszt, ha a költségvetés túlzottan laza, ha külső keresleti ársokk érvényesül, akkor a jegybanki függetlenség ellenére sem alakulhat ki az árstabilitásnak megfelelő alacsony inflációs környezet. „Egyetlen monetáris politikai rendszer, beleértve az inflációs cél követését, sem járhat sikerrel, ha fenntarthatatlan költségvetéssel szemben akar tartós inflációcsökkenést elérni." (Bernanke [2005]) Mégis több eséllyel kecsegtet az árstabilitás elérése, ha egy olyan intézmény őrködik felette, amelynek müködésében

\footnotetext{
${ }^{2}$ Az árstabilitásnál alacsonyabb infláció pedig az összkeresletre gyakorolt negatív hatás, az adósságok reálértékének emelkedése miatt okoz a potenciálisnál alacsonyabb növekedést.

${ }^{3}$ A politikai ciklusok és a gazdasági ciklusok közötti tapasztalati korrelációt helyezi szélesebb makroökonómiai keretekbe a politika által befolyásolt gazdasági ciklusok elmélete (Political Business Cycle - Nordhaus [1975]).

${ }^{4}$ A függetlenség hiánya mellett is előfordulhat tartósan alacsony infláció. A monetáris integráció előtt a Bundesbank nem élvezett magas fokú függetlenséget, az inflációellenes társadalmi konszenzus következtében mégis stabilak maradtak az árak Németországban. A közvélemény inflációs érzékenysége miatt nem politikai nyereséget, hanem veszteséget okozott volna az inflációt gerjesztő kormányzati politika. A legtöbb országban azonban nem létezik ilyen kulturális eredetű antiinflációs korlát.

${ }^{5}$ A számítások megalapozottságát és a végkövetkeztetést sokan vitatták. Többen az adatok megalapozottságát (alapvetően a függetlenség értékelését) kérdőjelezik meg. Mások a fejlett és kevésbé fejlett országok tapasztalatainak egybemosását kritizálták. Lásd például Cargill [1995], Eijffinger-Keulen [1995], Hayo [1998], Posen [1993].
} 
nincsenek jelen az újraválasztáshoz kapcsolódó rövid távú politikai érdekek, és amely nem is kényszeríthető ilyen érdekek által vezérelt utasítások végrehajtására.

2. A kormányzatok hajlamosak többet költeni bevételeiknél. Ha könnyü és olcsó a bevételeket meghaladó kiadásokhoz finanszírozási forrásokat találni, akkor nagyobb a késztetés a nagyobb hiányra. Ha a kormány hitelt vehet fel a jegybanktól (vagy állampapírokat adhat el neki), akkor ennek a hitelnek a mértékéig biztosan finanszírozható a hiány. Amennyiben viszont nem lehetséges a költségvetési hiány jegybanki finanszírozása, ${ }^{6}$ akkor a hiány mértékét a piaci finanszírozás lehetőségei határozzák meg. Ha történetesen elapadnak ezek a források, akkor a kényszer teremti meg a költségvetési egyensúlyt.

A jegybankot a kormány alárendeltségében tartó intézményi szerkezet mellett könnyen alakul ki magas költségvetési hiány. A jegybank ilyenkor könnyedén utasítható hitelkibocsátásra. Ennek a hitelnyújtásnak (állampapír-vásárlásnak) csak a kormány önkorlátozása szab gátat. De miért korlátozná magát az állam a hitelfelvételtől, ha a pótlólagos kiadásoktól nagyobb választói támogatást remél?

Ha a jegybank a kormányzati struktúrán kívül müködik, és nem utasítható az állam finanszírozására, akkor nagyobb az esély a fegyelmezett költségvetési politikára. Az esély azonban nem garancia. ${ }^{7}$ Az állítás annyi, hogy független jegybank mellett nehezebben, nem független jegybank mellett könnyebben - akár elégséges piaci finanszírozás hiányában is - létrejöhet magas hiány. Mivel a magas költségvetési hiány inflációt gerjeszt, az árstabilitásért felelős jegybank saját célrendszere alapján tartózkodni fog a magas deficitet lehetővé tevő jegybanki finanszírozástól. A legtöbb országban a jegybanktörvények ki is zárják a költségvetés finanszírozásának lehetöségét, ami egy paradoxont is tartalmaz. A függetlenség nagyobb szabadságot jelent, miközben a tilalom éppen azt a szabadságot veszi el a jegybanktól, hogy egyáltalán dönthessen úgy, hogy saját eszközeivel az államot finanszírozza.

A jegybanki függetlenség mellett tehát nemcsak az árstabilitás és a monetáris politika hatékonysága, hanem a költségvetési fenntarthatóság oldaláról is lehet érvelni.

3. A jegybank iránti közbizalom (hitelesség) azt jelenti, hogy a gazdaság szereplöi stabilnak tekintik és elfogadják a monetáris politika deklarált céljait, valamint elhiszik, hogy a jegybank elkötelezett, és képes mandátumának teljesítésére. Ha pedig a jegybank hitelessége alacsony, azaz a közönség nem bízik az árstabilitási cél teljesülésében, és ennek alapján alakítja a várakozásait, akkor az infláció nagy valószínüséggel magasabb is lesz. Minél hitelesebb egy jegybank, annál kisebb reálgazdasági költséggel jár az infláció elleni fellépése. Ha a jegybank a kormányzati struktúra része, akkor okkal vélelmezhetö, hogy deklarált célja érdekében nem lesz képes következetesen cselekedni. A gazdaságpolitika egésze számára az alacsony infláció nem elsődleges cél (lásd 1. pont), ezáltal a jegybank számára sem lehet az. A közönség okkal

\footnotetext{
${ }^{6}$ A hiány jegybanki finanszírozásához hasonló tartalmú fogalom a költségvetési finanszírozás, a költségvetési dominancia vagy az adósság monetizálása.

${ }^{7}$ A piaci befektetők - rövidlátásból, a pillanatnyi nyereség lehetőségétől hajtva - akár huzamosabb ideig is hajlandók lehetnek fenntarthatatlan költségvetéseket finanszírozni.
} 
tarthat attól, hogy a célt megváltoztatják, vagy a cél csak üres deklaráció. A jegybanki hitelesség szükséges feltétele, hogy a jegybank politikai befolyástól mentesen müködhessen. A független státusból azonban nem következik automatikusan a nagyfokú hitelesség. Ha a jegybank szakmai hibákat vét, ha politikai nyomásnak enged, ha exogén tényezők hatására sorozatosan nem teljesíti a célját, hitelessége csorbul.

A politikai gazdaságtani szerzők alapvetően a politikai tagoltság és az érdekviszonyok oldaláról közelítik meg a jegybanki függetlenség kérdését. Bernhard [1998] szerint koalíciós kormányzás esetén a partnerek közötti eltérő politikai preferenciák, a kormány és a saját törvényhozói közötti esetleges feszültségek könnyebben kezelhetők, ha a jegybank független, mert legalább az árfolyammal, inflációval és antiinflációs intézkedésekkel kapcsolatos viták nem terhelik a felek viszonyát. A népszerütlen intézkedésekért nem egymást, hanem a jegybankot lehet felelössé tenni. A jegybanki függetlenség a kormányzati stabilitás erösítésének egyik eszköze. A koalíciós partnerek közötti nagyfokú nézetazonosság, a politikai egyszínüség és a demokratikus berendezkedés hiányakor kevésbé lehet számítani a jegybankok függetlenségére. Crowe-Meade [2007] pozitív korrelációs kapcsolatot mutatott ki a jegybanki függetlenség és a demokratikus politikai berendezkedés között. Hallerberg [2002] szerint föderális berendezkedés esetén a helyi hatalom birtokosai támogathatják a jegybank függetlenségét, hogy ezzel is mérsékeljék a központi hatalom súlyát. De Haan-Eijffinger [2016] szerint minél nagyobb a politikai tagoltság egy országban (például koalíciós kormányzás, koalíciós partnerek közötti nézetkülönbségek, erős a fékek és erős ellensúlyok rendszere, föderális államszervezet), annál nagyobb a jegybank függetlenné válásának esélye.

Többen gazdasági érdekcsoportok lobbitevékenységével magyarázzák a jegybankok függetlenné válását. Ha az árstabilitás minden társadalmi csoport számára ugyanolyan fontos lenne, akkor egyetlen társadalmi csoportnak sem füzödne különleges érdeke a jegybanki függetlenséghez. Az infláció és a monetáris politikai döntések azonban eltérő módon érintik az egyes társadalmi csoportokat.

Posen [1995] szerint a magas és meglepetésszerü infláció legnagyobb vesztesei a pénzügyi szektor vállalatai, ezért az ő érdekükben áll leginkább olyan intézményi feltételek kialakítása, amelyek a legjobban segítik az árstabilitás megvalósulását. ${ }^{8}$ Posen interpretációjában az árstabilitás megvalósulásával az egész társadalom nyer, ezért a jegybanki függetlenség támogatásával a pénzügyi szektor vállalatai, miközben önérdeküket követik, a közjó érvényesülését is előmozdítják. Posent értelmezve Hayo-Hefeker [2001] így fogalmaz: „....nem is annyira a jegybanki függetlenségnek

\footnotetext{
${ }^{8}$ A bankok többnyire rövid lejáratú forrásokból finanszírozzák hosszabb lejáratú hiteleiket. A rövid lejáratú források kamata gyorsan követi az infláció alakulását. Ha a bankok hosszabb lejáratú hitelkamataikat is az infláció - átmenetinek tartott - megemelkedésével összhangban emelnék, akkor az infláció visszacsökkenését követő reálkamat-emelkedés a hitelek romló megtérülését okozná. Ha az infláció visszacsökkenésére számítva a bankok eleve az infláció megemelkedésénél (és a betéti kamatok emelésénél) kisebb mértékben emelik a hitelkamatokat, akkor a kamatrés szűkülése miatt csökkennek a nettó kamatbevételeik. Leginkább a hitelezési aktivitás visszafogása a magától értetődő banki válasz az infláció emelkedésére. Santoni sematikus példákon keresztül mutatja be, hogy a kereskedelmi bankokat hátrányosan érinti a nem anticipált és az anticipált infláció megemelkedése (Santoni [1986]).
} 
köszönhető, hogy a monetáris politika az alacsony inflációra törekszik. A jegybankárok csupán egy meghatározott társadalmi csoport, nevezetesen az alacsony inflációban leginkább érdekelt pénzügyi szektor érdekeit juttatják érvényre.” (17. o.)

Stiglitz szerint is a jegybank a pénzügyi szektor érdekeit juttatja érvényre. Posennel ellentétben azonban ő azt állítja, hogy eközben a magánérdekek a közjó rovására érvényesülnek. A pénzügyi érdekcsoportok személyi kapcsolataikon, a nyilvánosságon keresztül gyakorolnának nyomást a jegybankra annakérdekében, hogy nekik megfelelő monetáris politikai döntések szülessenek. „Amerika központi bankját foglyul ejtette a Wall Street: a Fed annak a pénzügyi szektornak az ideológiáját és érdekeit tükrözi, amelyet szabályozni hivatott. [...] A monetáris politika és a szabályozás delegálása azokhoz, akik a pénzügyi piacokról jönnek, és azok érdekeit tükrözik, olyan politikát eredményez, amely nem áll(t) a szélesebb társadalom érdekében." (Stiglitz [2013] 31. o.)

Stiglitz értékelése - ha általában a modern jegybankokra értjük - túlzó, megoldási javaslata azonban figyelemre méltó. Nem a jegybank kormányzat alá rendelését, hanem a jegybanki függetlenség és a szélesebb társadalmi képviselet kombinációját, ezáltal pedig a jelenleginél erösebb társadalmi kontrollt szorgalmazott a jegybank felett már tíz évvel a világgazdasági válság kitörése előtt. Kívánatosnak tartotta a fogyasztók, a kereskedők, a munkavállalók jegybanki képviseletét, amit nem a jegybanki függetlenség szükítésének, hanem a demokratikus berendezkedéshez való jobb megfeleltetésnek tekintett. (1998-ban ezt még megfelelő megoldásnak találta a társadalmi érdekek érvényre juttatásához - Stiglitz [1998].) Stiglitz értékelése azóta gyökeresen megváltozott (lásd később).

\section{A függetlenség tartalma, határai, a jegybank viszonya a végrehajtó hatalomhoz, a törvényhozáshoz és a választópolgárokhoz}

A jegybanki függetlenség jelen írás felfogása szerint nem vonatkozik a jegybank alapvető mandátumának és a monetáris politika középtávú céljának meghatározására. Demokratikus társadalmi berendezkedés mellett a választott kormányok a szavazópolgároknak tartoznak beszámolással. Miután a jegybankok a társadalom minden tagját érintő és hosszabb távra szóló döntéseket hoznak, a jegybank elszámolással tartozik a társadalom számára, hogy mit és miért tesz. A nem választott jegybankárok feletti társadalmi ellenőrzés (részben) azáltal valósul meg, hogy a jegybank számára követendő célokat a törvényhozás, illetve a kormány határozza meg (Mishkin [2011]).

A jegybank alapvetö feladatát a törvényhozás a jegybankra vonatkozó törvényben rögzíti, a középtávú célokat a kormány vagy a kormány és a jegybank együttesen határozza meg. A jegybank függetlensége a célok megvalósításához rendelt eszközök politikai befolyástól mentes használatában nyilvánul meg. Amennyiben a demokratikus ellenőrzésre hivatkozással az eszközök használata is kormányzati ellenőrzés alatt állna, akkor a kormány rövid távú politikai érdekei eltérítenék a jegybankot deklarált céljainak teljesítésétől. A befolyásmentes eszközhasználat viszont nem jelenti a társadalmi ellenőrzés hiányát. A jegybanki tevékenység az elmúlt évtizedek során az önállóság növekedésével összhangban lényegesen átláthatóbbá vált. 
A közvélemény jegybanki közlemények, publikációk, sajtónyilatkozatok, interjúk, parlamenti meghallgatások stb. révén szerezhet tudomást a jegybank tevékenységéről, és megismerheti a jegybanki döntések mögötti megfontolásokat. Az elszámolás átláthatóságon alapul (Cecchetti [2013]). Nem alaptalan azt gondolni, hogy nagyobb lehet az átláthatóság jegybanki önállóság esetén, mint akkor, ha a jegybank a kormányzati struktúrába tagolva, a nyilvánosság elől elzárva, apparátusi kompromiszszumok és változó politikai megrendelések teljesítésén dolgozik. ${ }^{9}$

A jegybanki függetlenség és az elszámoltathatóság egymás kiegészítői. Megfelelő elszámoltatási mechanizmusok - a függetlenség fékei és ellensúlyai - hiányában a jegybanki függetlenség káros lehet a társadalom számára. Az elszámoltatás csökkenti az ismétlődő szakmai tévedések, visszaélések, a magánérdekek előtérbe kerülésének kockázatát. Kényes azonban a határvonal a társadalmi ellenőrzést megvalósító elszámoltatás és a függetlenséget sértő politikai nyomásgyakorlás között. Ha a jegybank elnökének minden kamatdöntés után parlamenti politikusok elött kell bizonygatnia a jegybank döntésének megalapozottságát és hallgatnia politikusok értékelését a kívánatos kamatszintről, akkor inkább van szó politikai nyomásgyakorlásról, mint a jegybank demokratikus ellenőrzéséről (Bernanke [2016]).

A jegybanki függetlenség sok összetevőből épül fel, ezek kombinációja határozza meg a függetlenség mértékét. Az egyes összetevők nem helyettesítik, hanem kiegészítik egymást. A függetlenség alkotóelemei többféle szempont szerint csoportosíthatók, a csoportok pedig speciális (rész)függetlenségi fogalmak alapját képezhetik. Többféle osztályozás ismert. Az Európai Központi Bankáltal használt függetlenségfogalom például négy kategóriát különböztet meg: funkcionális, személyi, intézményi, pénzügyi (vagy gazdasági) függetlenséget. Több akadémiai írás is ezt a csoportosítást használja (Pisha [2011], Vasile [2013]). Gyakori a politikai és müködési függetlenség megkülönböztetése (Ueda-Valencia [2012], Balls és szerzőtársai [2016]).

A leggyakrabban azonban a cél- és eszközfüggetlenség megkülönböztetést használják, amelyet Debelle-Fischer [1994] vezetett be. A célfüggetlenség azt jelenti, hogy a jegybank maga határozza meg a monetáris politika célját. Az eszközfüggetlenség pedig a monetáris politika szabadságát jelenti a célok teljesítésében. „Egy eszközfüggetlenséggel rendelkezö bank szabadon választja meg az eszközöket, amelyekkel céljait el akarja érni." (I. m. 197. o.)

$\mathrm{Az}$ akadémiai irodalomban és a gyakorlati életben lényegében véve konszenzus van arról, hogy a jegybankok ne élvezzenek célfüggetlenséget. ${ }^{10}$ Alapvetően a túlzott hatalomkoncentráció a politikai függetlenséggel szembeni fö ellenérv (lásd például Mishkin [2007], [2011] vagy Debelle-Fischer [1994]). Ezt elfogadva, e cikk kereteiben is az

\footnotetext{
${ }^{9}$ A nagyobb transzparencia nemcsak az elszámoltatást, hanem a monetáris politika kiszámíthatóságát és ezen keresztül eredményességét is segíti. Ha a piacok szereplői ismerik és értik a jegybank müködését, a jegybank várható lépéseivel is jobban tudnak kalkulálni.

${ }^{10}$ Ez alól kivételt jelent Ueda-Valencia [2012] vagy Rogoff [1985]. Rogoff a monetáris politika egészét tenné az úgynevezett konzervatív jegybankár felelősségévé. A gyakorlati életben pedig az Európai Központi Bank státusa áll legközelebb a célfüggetlenséghez, ugyanis miközben az uniós alapszerződés az Európai Központi Bank alapfeladataként jelöli meg az árstabilitás elérését, annak konkrét mértékét és a középtávon elérendő monetáris politikai célt már maga az Európai Központi Bank határozza meg.
} 
eszközfüggetlenség értelmében használjuk a jegybanki függetlenség fogalmát. Érdemes azonban megjegyezni, hogy célfüggetlenség nélkül is indokolt a jegybank aktív részvétele a monetáris politika céljainak meghatározásában. Nagy valószínüséggel sikertelen lesz az a monetáris politika, amelyik kívülről ráerőltetett célokat követ. A célmeghatározás során csak a jegybank és a kormányzat közötti szoros kooperációval érvényesülhetnek a szakmai megalapozottság és a demokratikus eljárásmód követelményei egyidejüleg. Ebben a tekintetben a pénzügyi válság új tanulsággal nem szolgált, az együttműködés ezen a téren a válság elött is indokolt volt.

A politikai függetlenség tágabban értelmezett fogalma ${ }^{11}$ a célok meghatározásán kívül magában foglalja a kinevezésre és felmentésre vonatkozó eljárási rendet, a kormányzat képviseleti jogát a jegybank döntéshozó testületének ülésein, valamint az érdek-összeférhetetlenségre vonatkozó szabályokat is. Ezáltal azonban olyan összetevőket vesznek egy kalap alá, amelyek lényegesen különböznek a monetáris politika eredményessége szempontjából. Miközben a célfüggetlenség nem, a politikai függetlenség más elemei elengedhetetlenek az árstabilitás eléréséhez. Ezért nem célszerủ a politikai függetlenség kategóriájának a használata, és vitatható Balls és szerzötársai [2016] azon álláspontja, amely szerint a „fejlett gazdaságokban csak a müködési függetlenség fontos" (19. o.). ${ }^{12}$ Nagy valószínűséggel állítható, hogy a monetáris politika autonómiája sérül, ha történetesen a jegybank elnöke a hivatalából bármikor elmozdítható, és/vagy kinevezése többször ismételhető, és/vagy a kinevezés időtartama nagyon rövid, és/vagy a kormányzat képviselője részt vesz a kamatmeghatározó üléseken.

Az eszközfüggetlenség kategóriája a már említett kinevezési-felmentési szabályokon kívül tartalmazza a monetáris politikai döntéshozatal szabadságát (külső befolyástól való mentességét), az állam jegybanki finanszírozásának korlátozását, a jegybank gazdálkodási önállóságának és a gazdálkodási eredmény allokációjának szabályait. A sok összetevő esetlegesen eltérő alakulása miatt nem könnyủ a függetlenség tényleges állapotára következtetni.

\section{A mérés és a mérési eredmények értelmezésének nehézségei (de jure versus de facto függetlenség)}

A függetlenség valamilyen számszerűsített mértékének kifejezésére sok eljárás ismert. A módszerek ősforrásait a Cukierman-Webb-Neyapti- (CWN-) és a GrilliMasciandaro-Tabellini-indexek jelentik (Cukierman és szerzőtársai [1992], Grilli és szerzötársai [1991]). Mindkét eljárás a függetlenség részösszetevőinek összesí-

${ }^{11}$ A politikai függetlenség nem általában a politikától való függetlenséget jelenti. Politikai befolyás az eszközök használata során is érvényesülhet. Ezt a működési függetlenség értékelésekor vesszük figyelembe.

${ }^{12}$ „....a politikai függetlenség és az infláció alakulása között nincs korreláció. Ezért saját legitimációjuk védelméért a fejlett gazdaságokban a jegybankok anélkül áldozhatják fel politikai függetlenségük egy részét, hogy aláásnák müködési függetlenségüket, ami viszont lényeges mind a monetáris politika, mind a pénzügyi stabilitás szempontjából." (Balls és szerzőtársai [2016] 2. o.) 
tett értékelésén alapul. ${ }^{13} \mathrm{Az}$ indexek alapján az egyes jegybankok elhelyezhetők egy függetlenségi skálán, és időbeli összehasonlítások is végezhetők. A mérési eljárások későbbi finomítása, új változók figyelembevétele, egyes változók elhagyása, a felhasznált adatforrások módosítása újabb és újabb függetlenségindexeket eredményezett (például Crowe-Meade [2007], Dincer-Eichengreen [2014], Arnone és szerzötársai [2007], Masciandaro-Romelli [2017]). A mérési eljárások részletes bemutatása nem tárgya írásunknak. (A CWN-index ${ }^{14}$ illusztrálására lásd Cukierman és szerzőtársai [1992] 358-359. o.) Szinte a függetlenségi mutatók bővülésével arányos a számítási eljárások bírálatainak száma. A legtöbb kritika a szerepeltetett vagy éppen nem szerepeltetett változókkal, az értékelések és a súlyozási rendszer szubjektív elemeivel kapcsolatos.

A különböző eljárásokat alkalmazó mérések egybehangzó következtetése az, hogy a jegybanki függetlenség a 2000-es évek elejére - az 1990-es évek elejének alacsony szintjéröl indulva - igen magas szintet ért el. Crowe-Meade [2007] 2003-as adatokon - de az eredetinél szélesebb országkörre vonatkoztatva - kiszámolta a CWN-index értékét. Az eredmények a jegybanki függetlenség érdemi növekedését mutatták. Különösen a feltörekvő országok - és azon belül a kelet-közép-európai EU-tagállamok - jegybankjainak függetlensége emelkedett látványosan. ${ }^{15} \mathrm{~A}$ függetlenség de jure és de facto megkülönböztetése azonban árnyalja ezt a képet. A függetlenségi indexek azt mérik, hogy a jegybankra vonatkozó formális szabályok milyen autonómiát biztosítanak, márpedig a „de jure intézményi szabályok nem jó jelzői a tényleges függetlenségnek" (Vuletin-Zhu [2011] 1209. o.). ${ }^{16}$ A jogi függetlenség méröszámai többnyire túlbecsülik a jegybankok tényleges függetlenségének mértékét. A de facto függetlenség nehezen mérhetö, a közvélemény előbb-utóbb mégis felismeri, ha egy jegybank csak papíron független, és ez komoly hitelességi/várakozási problémák forrása lehet. Az alábbiakban a de jure és de facto értelemben vett függetlenség eltérésének néhány megnyilvánulásával foglalkozunk.

A különböző indexek annál függetlenebbnek tekintik a jegybankot, minél nagyobb a parlament vagy a pártok felett álló államfö befolyása a jegybankelnök (jegybanki döntéshozók) kinevezésére. ${ }^{17}$ A valóságban a kormány (miniszterelnök) meghatározó szerephez jut akkor is, ha formális jogosítványa csak a kezdeményezésre korlátozódik, a

${ }^{13}$ A két eljárás részletesebb összehasonlítása megtalálható például Masciandaro-Romelli [2017] vagy Mangano [1998] munkáiban.

${ }^{14} \mathrm{Az}$ CWN-index 16 változót szerepeltet, amelyeket 0 és 1 közötti skálán értékel, majd négy klasztert képez belőlük, amelyek a komponensek átlagának értékeit veszik fel. Végül a klaszterekből meghatározott súlyrendszer alapján alakul ki a végső érték. (Ezen értékeket tartalmazó táblázat letölthető a http:// documents.worldbank.org/curated/en/797831468739529187/pdf/multi-page.pdf címről.)

${ }^{15}$ Hasonló eredményre jutott Balls és szerzőtársai [2016], Dincer-Eichengreen [2014] és Arnone és szerzőtársai [2007].

${ }^{16}$ Cargill [2016] szerint a de jure függetlenség legjobb esetben is csak a jegybank és a kormány közötti kapcsolat nagy eltolódásainak jelzésére alkalmas. A fogalom tisztázatlanságai és a mérés nehézségei miatt a függetlenségfogalom használatának elvetését, helyette pedig az elszámoltathatóság és transzparencia alkalmazását javasolja.

${ }^{17} \mathrm{Az}$ említett CWN-index 0 pontértéket ad arra az esetre (nem tekinti függetlennek a jegybankot) , ha a jegybank elnökét a kormány nevezi ki, és magasabbat, ha a kormány szerepe a kinevezési folyamatban korlátozott. 
parlamentnek (vagy parlamenti bizottságnak) jóváhagyási jogköre van, a formális kinevezést pedig az államelnök teszi. A miniszterelnöki javaslat visszautasítása inkább csak formális lehetőség az államelnök és a parlament számára. Különösképpen igaz ez, ha a parlament és az államfö nem tölt be hatalmikontroll-funkciót. A kormányok képesek elérni, hogy a kinevezési folyamat végén olyan személy kerüljön a jegybank élére, aki a kormányzat politikai preferenciáinak leginkább megfelel, és aki személyi biztosítékot jelent arra, hogy a jegybank is e preferenciáknak megfelelően fog müködni. ${ }^{18}$ Felértékeli a kiválasztás fontosságát, hogy a kinevezést követően jelentősen beszükülnek a monetáris politika befolyásolásának lehetőségei, és a nem megfelelő személy elmozdítására jogi lehetőség sincs. ${ }^{19}$ Ha nem szuverén módon gondolkodó személyek a jegybank döntéshozói, akkor a legfüggetlenebb kinevezési, felmentési, összeférhetetlenségi szabályok mellett - utasítások, közvetlen nyomásgyakorlás nélkül - is a kormány alárendeltségében fog működni a jegybank. Stiglitzcel ellentétben azt mondhatjuk, hogy nagyobb a kockázata annak, hogy a jegybank a kormány (rövid távú politikai érdekei), semmint a gazdasági érdekcsoportok (gazdasági magánérdekek) foglyává váljon.

A jegybankelnökök (és a jegybanki döntéshozók) mindenképpen politikai kinevezettek. Vuletin-Zhu [2011] empirikus vizsgálata a következőket állapította meg. ${ }^{20}{ }_{\text {„A minta }}$ egészében a távozó jegybankelnök felváltása egy szövetséges jegybankelnökkel viszonylag kis gyakoriságú, az összes elnökváltás 5,4 százalékára rúg. Érdekes, bár nem meglepő módon ezen a téren jelentős eltérés mutatkozik a fejlödő és a fejlett országok között. Miközben a fejlett országokban a jegybankelnökök nem minisztériumok vagy kormányintézmények legfelsőbb pozícióját adják fel új megbízatásukért, addig a fejlődő gazdaságokban a kormányzati pozíciót követő jegybankelnöki beosztás az összes jegybankelnökváltás 8,5 százalékában fordult elö. Ez a gyakorlat a mintában szereplő 21 fejlődő országból 11 esetében előfordult.” (1192. o.) „...vitathatatlanul a jegybank kormányzati foglyul ejtésének legvilágosabb esetét képviseli egy olyan személy jegybankelnöki kinevezése, aki a kinevezés pillanatában egy minisztérium vagy valamilyen kormányzati intézmény legmagasabb rangú vezetője volt." (1191. o.)

A kormányok azonban nem feltétlenül arra használják a kiválasztási folyamatban rendelkezésükre álló lehetőségeket, hogy bábokat ültessenek a jegybank élére. A politikusi önmérséklet, a hosszabb távú szempontok iránti érzékenység azt diktálja, hogy még egy „baráti” jegybankelnöktől sem a rövid távú hatalmi, politikai érdekek kiszolgálását várják. Ennek megnyilvánulása lenne a többpárti támogatás keresése a kinevezési kezdeményezés során vagy külső szakértők meghívása a kiválasztott személyek parlamenti meghallgatásakor. Leginkább a vezető piacgazdaságok kormánypolitikusai tettek tanúbizonyságot előrelátó képességről, a hosszabb távú

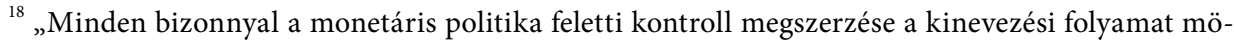
götti legfőbb mozgatórugó.” (Ennser-Jedenastik [2013] 504. o.)

19 „A politikusok abban érdekeltek, hogy a kormányzathoz igazodó preferenciákkal (governmentaligned preferences) rendelkező személyeket nevezzenek ki a monetáris tanácsokba, és elmozdítsák azokat, akik szembehelyezkednek a kormányzati politikai lépésekkel.” (Ennser-Jedenastik [2013] 503. o.)

${ }^{20}$ Vuletin-Zhu [2011] 42 ország (21 fejlett és 21 fejlődő ország) bankelnökváltásainak adatait elemezte 1972-2006 között. Összesen 257 esetet vizsgáltak meg. A kormányzat szövetségesének azt a jegybankelnököt tekintették, aki a kinevezését megelőző egy éven belül magas szintű kormányzati pozíciót töltött be. 
szempontok tiszteletéről, belátásról és nagyvonalúságról a bankelnökök kiválasztási folyamata során. A személyek kvalitásai mellett a politikai kultúra állapota, a politikai erőviszonyok is fontos szerepet játszanak ebben a folyamatban. Másrészt a kiválasztott elnökön is múlik, hogy milyen mértékben sérül a jegybank önállósága egy „baráti” kinevezés esetén. A jegybanktörvény elöírásainak való megfelelés, a jegybanki ethosz követése, a szakmai hitelesség igénye összeütközésbe kerülhet a kinevezö politikai elvárásaival. A jegybankelnök (és a jegybanki döntéshozók) személyes választása dönti el, hogy e konfliktus esetén minek ad(nak) elsőbbséget.

Miközben tehát a függetlenségi indexek a kinevezésre vonatkozó szabályok alapján sok esetben a jegybank jelentős függetlenségét mutatják, a valóságban a kinevezési folyamat számottevő lehetőséget biztosít a politikai befolyás érvényre juttatására. A kormányzati szándékok érvényesítésének más eszközei is vannak. A jegybankelnök (és a döntéshozók) személyi függetlenségének különböző dimenziói minden függetlenségi index részét képezik. Meglepő ugyanakkor, hogy a személyes jövedelem meghatározásának és változtatásának módjára vonatkozó szabályok nem szerepelnek az indexek változói között. Ebből következően a mandátum futamideje alatt a politikai retorzióként vagy politikai jutalomként alkalmazott jövedelemváltoztatásra ezek az indexek érzéketlenek. A jövedelemváltoztatás pedig nyilvánvaló kísérlet a monetáris politika megváltoztatására vagy a meglévő irány megerősítésére. Egyben jelzés a következö jegybankelnökök (döntéshozók) számára, hogy személyes jövedelmük függ majd a monetáris politika kormányzati megítélésétől. Komoly strukturális probléma és müködési zavarok forrása, ha a jegybank alapvető mandátuma és a legföbb jegybanki döntéshozók személyes jövedelmi viszonyai nincsenek összhangban egymással. ${ }^{21}$ Ezért a kinevezés pillanatától a kinevezés végéig terjedő időre elöre rögzített jövedelemszabály a jegybanki függetlenség és a jegybanki mandátum sikeres teljesítésének elengedhetetlen feltétele.

Mindezeken túl a jegybank és a kormány közötti szakmai viták több alkalommal vezettek a jegybankelnök távozásának idő előtti kikényszerítésére. A távozás kikényszerítése a jegybanki függetlenség nyilvánvaló csorbítása, a lépés célja a monetáris politika megváltoztatása. Az ilyen precedensek pedig arra ösztönözhetik a következő jegybankelnököket, hogy - tanulva elödeik tapasztalatából - minél kevesebb konfliktust vállaljanak a kormánnyal. A viták hátterében a leggyakrabban a monetáris politikának a gazdasági növekedéshez és a költségvetés mozgásterének bővítéséhez való hozzájárulás körüli nézeteltérés állt. Mivel a felmentési szabályok általában nem adnak lehetőséget politikai mérlegelésre, és minimális lehetőséget hagynak a kormánynak a jegybankelnök elmozdítására, a politikai nyomásgyakorlás volt az elmozdítás fö eszköze. A lemondás kikényszerítése a zárt ajtók mögötti rábeszéléstől a jegybankelnök szakmai rátermettségét, emberi tisztességét, állampolgári lojalitását megkérdőjelező, nyílt támadásokig terjed. A már említett Vuletin-Zhu [2011] vizsgálat azt állapította meg, hogy a fejlett gazdaságokban 93 bankelnökváltásból 28, a fejlődő gazdaságokban

\footnotetext{
${ }^{21}$ A jegybanki vezetők - anyagi - érdekeltté tétele a jegybanki célok, például inflációs cél teljesülésében, káros következményekkel is járhat. A személyes anyagi előnyök miatt a jegybankelnök akkor is erőltetheti az inflációs cél elérését, ha az túlzott reálgazdasági áldozatokkal jár.
} 
pedig 164 esetből 105 az elnöki mandátum lejárata előtt történt. Számszerü becslést nem ad a szerzőpáros, de az idő előtti váltások egy részét az „engedetlen” jegybankárok elleni politikai támadásokkal magyarázza.

Ennser-Jedenastik [2013] a jegybankelnökök és a kormányok, illetve államelnökök pártkapcsolatai közötti összefüggést vizsgálta harminc európai országban, 196 jegybankelnök esetében 1945 és 2012 között. Megállapította, hogy azok a jegybankelnökök, akik a végrehajtó hatalomhoz tartozó párt valamelyikéhez köthetők (party affiliation), lényegesen hosszabb időt töltenek hivatalukban, mint a pártoktól független (nonpartisan) jegybankelnökök, akikhez képest viszont az ellenzéki pártokhoz kötődő jegybankelnökök hivatalban töltött ideje még rövidebb.

A jogi függetlenség a monetáris politika döntéshozatali szabadságát is magában foglalja. A függetlenségi indexek magas pontszámmal jutalmazzák, ha a kormány nem adhat, a jegybank pedig nem fogadhat el utasítást a monetáris politikai eszközök használata során. A valóságban azonban gyakori a politikai nyomásgyakorlás. ${ }^{22}$ Személyes találkozók, telefonhívások mellett sajtónyilatkozatokban elejtett, burkolt célzásoktól leplezetlen követelésekig és fenyegetésig széles a befolyásolás spektruma. ${ }^{23}$ Egyes döntéshozók a legenyhébb jelzésre is alkalmazkodnak politikai elvárásokhoz, mások viszont a legerőszakosabb nyomásnak sem engednek. A jegybankok számára talán még nagyobb kihívást jelent a közvélemény elvárásainak kezelése. A közvélemény szándékolt szembeállítása a jegybankkal a politikai nyomásgyakorlás egy formája. A jegybank társadalmi elfogadottságának gyengülése a monetáris politika eredményességét is gyengítheti, mert ilyen helyzetben kevésbé valószínü, hogy a piaci várakozások a jegybank által remélt módon alakulnak. A függetlenség és társadalmi elszigetelődés közötti választás kompromisszumok vállalására késztetheti a jegybankot.

Elöfordul olyan eset is, amikor a de facto függetlenség meghaladja a de jure függetlenség mértékét. Egy jogi értelemben kevéssé független jegybank is képes lehet a monetáris politikai szempontok hatékony érvényesítésére, ha a jegybank vezetője szakmai felkészültségénél, személyes meggyőző erejénél, a miniszterelnökkel fennálló bizalmi kapcsolatánál fogva jelentős érdekérvényesítési képességgel rendelkezik. Minthogy ez a képesség konkrét személyekhez kötött, az ebből eredő de facto függetlenség addig haladja meg a jogszabályok által meghatározott függetlenséget, amíg a kulcsszereplök a helyükön vannak.

Összességében az állapítható meg, hogy a jegybankok függetlensége a válságot megelöző két-három évtizedben határozottan növekedett, ám a tényleges függetlenség jellemzően kisebb volt annál, mint amit a formálisan rögzített szabályok és a függetlenségi indexek számszerü értékei mutattak.

${ }^{22}$ A pénzügyi szektor képviselői, a munkáltatók, a szakszervezetek, az akadémiai körök, nemzetközi szervezetek is gyakran véleményt nyilvánítanak a követendő monetáris politikával kapcsolatban. Ezek hasznos visszajelzést adnak a monetáris politika számára. Ezektől megkülönböztetendő a politikai nyomásgyakorlás, amelyen a jegybankot mandátumának teljesítésétől eltérítő kormányzati beavatkozást értjük.

${ }^{23}$ Havrilesky [1993] politikai nyomást mérő mutatószáma +1 értéket ad minden olyan sajtó-előfordulásnak, amely szigorítást szorgalmazó kormányzati igényekről szól, és -1 értéket ad a lazításról szólónak. A végeredmény előjele és nagysága alapján következtet a politikusi befolyásolás erejére és irányára. 


\section{A függetlenség tartalmának és határainak változása a válság után}

A válság utáni visszaesést sok országban nem gyors helyreállítás, hanem évekig tartó alacsonyabb növekedés követett. A lecsökkent infláció pedig sok helyen tartósan alacsony maradt. A hagyományos gazdaságpolitikai eszközök nem voltak alkalmasak a folyamatok megfordításához: a költségvetési élénkítésnek a legtöbb helyen határt szabott az államadóssági ráta magas szintje, a jegybanki élénkítésnek pedig a nulla kamatszint. Azok az országok kezelték legsikeresebben a válság elhúzódó következményeit, amelyekben a monetáris politika és a költségvetési politika szorosan együttmüködött, és a jegybank korábban a költségvetés feladatkörébe tartozó funkciókat látott el. Ilyenek voltak a válság akut szakaszában a jegybank által finanszírozott vállalati mentöprogramok (kedvezményes hitelek, eszközvásárlási akciók), amelyek gyorsabb és hatékonyabb válságkezelést tettek lehetővé, mint a hosszadalmas államigazgatási egyeztetések és parlamenti jóváhagyás útjának végigkövetése.

Lehet vitatni, hogy a tűzoltás során a jegybankok túlterjeszkedtek-e a nekik kijelölt feladatokon. Az állampapír-vásárlások számottevő költségvetési következményekkel járnak. Az állampapír-portfólión realizált nyereség, illetve a portfólió későbbi leépítése nyomán keletkező árfolyamnyereség/-veszteség érinti a költségvetés pozícióit. Felvethetö, hogy a jegybankok csak kormányzati egyetértés mellett vállalhassanak hitel- és kamatlábkockázatot. Mindez azt indokolja, hogy újragondoljuk a jegybanknak a gazdaságpolitika egészében betöltött intézményi helyzetét, monetáris politikai céljait és a jegybanki függetlenség indokoltságát. Ez a gondolkodás megkezdődött, és ennek keretében korábban már lezártnak vélt viták is újraéledtek.

A hagyományos érvelés szerint a jegybanki függetlenség a magas infláció elleni eredményes fellépés szükséges feltétele. Alacsony infláció esetén azonban a jegybanknak nem kell megvédenie az árstabilitás ügyét a kormánnyal szemben, mert a jegybank és a kormány egyaránt ennek elkerülésében érdekelt. Az - árstabilitást veszélyeztető - emelkedő infláció esetén a kormányzati élénkítés káros, túl alacsony infláció esetén viszont hasznos, még akkor is, ha mögötte a politikusok újraválasztási megfontolásai állnak. Summers [2016] szerint a jegybanki függetlenség „olyan makrogazdasági problémára vezethető vissza, amelynek a mai időkben már nincs relevanciája”, ma a szekuláris stagnálás, a krónikus kereslethiány és az alacsony infláció a fö makrogazdasági probléma. Lynn [2012] szerint ,a független, technokrata jegybank modellje leáldozóban van, és felváltja a monetáris politika feletti közvetlen kormányzati ellenőrzés".

Ha Summersnek igaza van, és ha hosszabb távon is az árstabilitás szintje alatt marad az infláció, akkor nem lesz szükség független jegybankra. Ha viszont a növekedési és áremelkedési ütemek csökkenését egy elhúzódó válság átmeneti következményeinek tekintjük, és hosszabban elöretekintve a növekedés és az áremelkedés ütemének gyorsulására számítunk, akkor a jegybanki függetlenségre is szükség lesz. A függetlenség feladása vagy érdemi korlátozása nagy valószínűséggel a várakozások ellenőrizetlenné válásához vezet, ami az infláció későbbi visszaemelkedésekor jelentősen megnehezítheti a jegybankok dolgát. Ezért a jegybank politikai befolyástól mentes müködése (eszközfüggetlenség) egyaránt indokolt magas és alacsony infláció mellett (Fischer [2016], Balls és szerzőtársai [2016]). 
A költségvetési finanszírozás kategorikus elutasítása (a jegybanki függetlenség elvi alapjainak második nagy pillére - lásd tanulmányunk elején a 2. pontot) mögötti korábbi konszenzus megszűnt. Elvi viták még zajlanak, de a gazdaságpolitikai gyakorlat a mennyiségi lazítási programok indításával már ledöntötte ezt a tabut. Felfogásunk szerint a nagyarányú jegybanki állampapír-vásárlás - függetlenül attól, hogy az elsődleges vagy a másodlagos piacon történik - összeütközésben áll a költségvetési finanszírozás tilalmával. A költségvetési finanszírozás tilalma megnehezíti, a jegybanki állampapír-vásárlás pedig megkönnyíti a magasabb hiány kialakulását. A jegybanki vásárlások nem jelentenek problémát mindaddig, amíg a makrogazdasági stabilizáció és az infláció emelése érdekében a költségvetési élénkítésnek van tere. A jegybanki értékpapír-vásárlások által kiváltott hozamcsökkenés mérsékli a fennálló államadósság törlesztési terheit, forrásokat szabadít fel az állam számára, amelyek a folyó kiadások növelésére fordíthatók. Az olcsóbb finanszírozás lehetösége további állami költekezésre is ösztönöz.

Ennél azonban többről is szó van. A jegybank portfóliójában lévő állampapírok után fizetett kamat a jegybank eredményét növeli. A jegybanki eredmény viszont az országok döntő többségében az államháztartási bevételeket gyarapítja, ami azt jelenti, hogy - arra az időre, amíg a jegybank portfóliójában vannak - végeredményben nulla kamatozásúakká válnak a jegybank birtokában lévő állampapírok. Amit az állam a jegybanknak kamatként kifizet, jegybanki profit formájában viszszakapja. ${ }^{24}$ Vannak azonban, akik messzebb mennek, és az állam nyílt jegybanki finanszírozását (friedmani helikopterpénz alkalmazását) javasolják (például Turner [2015] vagy Bossone [2015]).

Ha a jegybank az állam számláján jóváír egy összeget, úgy tesz lehetővé adócsökkentést vagy kiadásnövekedést, hogy közben az állam adósságállománya nem növekszik. Adósságnövekedés hiányában nem kell tartani egy adómérséklést követő kényszerű adóemeléstől, ezáltal az adómegtakarítás fogyasztói (vagy beruházási) keresletté válva stimuláló hatást gyakorol mind a gazdasági aktivitásra, mind pedig az árakra. ${ }^{25}$ Ugyanaz, ami korábban a költségvetési finanszírozás elleni fő érv volt, ma a mellette szóló érv: szabad utat nyit a költségvetési kiadások növeléséhez. Korábban azért kellett megtiltani a költségvetési finanszírozást, hogy gátat lehessen szabni a költségvetési kiadások növekedésének (és ezáltal az infláció megemelkedésének). A válság utáni reálgazdasági apály és deflációs veszély idején pedig az szól mellette,

${ }^{24}$ Lejáratig tartott állampapír esetén a jegybanknak fizetett tőketörlesztés attól függően teszi az állam számára teljesen költségmentessé az adósságot, hogy a tőketörlesztést profitnövelő bevételnek tekintjük-e. Ez pedig a jegybanki állampapír-vásárlásra fordított új jegybankpénzzel kapcsolatos seignorage értelmezésén múlik. A hagyományos nyílt piaci műveletek keretében végrehajtott jegybanki állampapír-vásárlás tipikusan rövid időszakra irányul. Ez különbözteti meg a költségvetési finanszírozástól, ami az adósság végleges megvásárlását jelenti. A nyílt piaci műveletek időhorizontja rövid, a mennyiségi lazításé hosszabb, az adósság monetizálásáé végtelen.

${ }^{25}$ „A nyílt pénzfinanszírozás (overt money financing) a defláció leghatékonyabb megoldási eszköze, különösen azokban a magas eladósodottsággal és nyomott teljesítménnyel terhelt országokban, amelyek semmilyen vagy csak korlátozott költségvetési mozgástérrel rendelkeznek. ...lehetővé teszi, hogy új vásárlóerőt teremtsen, és azt azoknak juttassa, akiknek legnagyobb szükségük van rá, és akik leginkább el fogják költeni." (Bossone [2015].) 
hogy képessé teszi a költségvetést a gazdaság élénkítésére. A költségvetési finanszírozással kapcsolatos tolerancia azonban csak átmeneti lehet. A jegybanki állampapírvásárlás fenntartása a rendkívüli körülmények megszüntével ellentmondásba kerül a költségvetés fenntarthatóságának és az árstabilitásnak a szempontjaival. Nincs tapasztalat arra, hogy az alacsony infláció milyen gyorsasággal vált át magas inflációra, és ennek következtében milyen gyorsasággal kell az érintett jegybankoknak átállni állampapír-vásárlásról állampapír-eladásra.

A korábbi érvelés szerint a költségvetési finanszírozás megakadályozása érdekében volt szükség a jegybank függetlenségére. A tilalom átmeneti felfüggesztése mégsem gyengíti a jegybaki függetlenség fontosságát. Ha a jegybank által vásárolt értékpapír mennyisége vagy a nyílt jegybanki finanszírozás volumene (ha van ilyen) politikai alkufolyamatban dőlne el, akkor nagy lenne a veszélye az ellenőrizetlenné váló pénzmennyiségnövekedésnek. ${ }^{26}$ Továbbá a végrehajtó hatalom demokratikus ellenőrzésének az elve is sérül, ha a kormány bevételi igényeit a parlamenti felhatalmazást igénylö adókivetés helyett a befolyása alatt álló jegybankprés müködtetésével elégíti ki.

A jegybanki függetlenség melletti régi érveket a megváltozott makrogazdasági körülmények új megvilágításba helyezték, de megalapozottságukat nem kérdőjelezték meg. Felmerülnek azonban korábban mellőzött szempontok is. A pénzügyi válság legfontosabb tanulsága az, hogy a monetáris politika felelős a pénzügyi stabilitás megőrzéséért (és felelős volt a pénzügyi stabilitás megrendüléséért). Ez a felelösség kettős: egyrészt a már bekövetkezett károk kezelésében, másrészt a jövőbeli károk elkerülésében nyilvánul meg. A rendszerkockázattal fenyegető vállalati csődök elhárításában való közreműködés hagyományosan a jegybank végső hitelezői feladatából következik (lender of last resort). A jegybank rendelkezik azokkal az információkkal és szaktudással, amelyek alapján megítélhető, hogy egy vállalat bukása elindít-e a pénzügyi stabilitás egészét fenyegető láncreakciót. A jegybank képes a mentőakciók pénzügyi fedezetét előteremteni. A mentőakciók azonban jelentős politikai következményekkel is járnak. ${ }^{27} \mathrm{~A}$ mentőakciókkal kapcsolatos politikai felelősséget és azok politikai legitimitását az biztosíthatja, ha egy-egy vállalatmentő beavatkozás a jegybank és a kormányzat közös döntésén alapul. A jegybank nem menthet meg magánvállalatot a kormány egyetértése nélkül; a kormány pedig nem utasíthatja a jegybankot valamely vállalat megmentésére.

A jövőbeli károk megelözéséről a makroprudenciális politika gondoskodik. A pénzügyi válság elött a jegybankok és kormányok hallgatólagosan azt feltételezték, hogy a liberalizáltan müködő piacok megteremtik a pénzügyi stabilitást, s így a kormányzati és jegybanki politikának nincs érdemi teendője ezen a területen. A rendszerkockázattal

${ }^{26}$ „A mennyiségi lazítással kapcsolatos jegybanki döntések indokolatlan kormányzati befolyásolásának költsége rendkívül nagy lehet, miután ez a befolyás egyenértékű azzal, hogy a kormány lehetőséget kap az adósság monetizálására, amit pedig minden áron szükséges elkerülni." (Bernanke [2010].)

${ }^{27}$ Elkerülhetetlenül erősen átpolitizált viták kereszttüzébe kerül minden vállalati mentőprogramot finanszírozó jegybanki akció. A bírálatokban elhangozhat magánérdekeket szolgáló állami ajándék (Stiglitz), a mentőakciók nagyobb kockázatvállalásra ösztönző szerepe (moral hazard), elmulasztott vagy rosszul időzített jegybanki beavatkozás miatti makroválság (Lehman Brothers), a politikai elvárásoknak való behódolás egyaránt. 
járó egyedi vállalati problémákra pedig a jegybank végső hitelezői funkciója kielégítő megoldást biztosít. Ez tévedés volt. A válság óta tudható, hogy rendszerkockázatok úgy is kialakulhatnak, hogy a legjelentősebb vállalati szereplők mind sikeresek, és a monetáris politika is eredményesnek látszik. A válság hatására előtérbe került a makroprudenciális politika, ami újabb feladatot jelent a jegybankok, pénzügyi szabályozó hatóságok és a kormányzati gazdaságpolitika számos intézménye számára. Ezek a feladatok azonban nem hagyhatók teljességgel technokrata szakértők kezében, mert ellátásuk széles körü elosztási hatásokkal és politikai következményekkel jár. Ezért a jegybank nem lehet a pénzügyi stabilitás egyedüli felelőse.

Több országban a törvényhozók ennek megfelelően - az elsődleges cél fenntartása mellett - kiegészítették a jegybankok mandátumát. A pénzügyi stabilitás feltétele annak, hogy a jegybank el tudja látni elsődleges feladatát. Tehát a jegybank alapvető mandátumából is levezethető a pénzügyi stabilitás fenntartása mint monetáris politikai cél. A feladatok között azonban konfliktusok is lehetségesek. Ezért tisztázni kell a monetáris politikai célok egymáshoz való viszonyát, valamint a jegybank viszonyát a pénzügyi stabilitásban szerepet játszó más intézményi szereplőkhöz. Nehezíti a helyzetet, hogy a pénzügyi stabilitás nem jellemezhető egyetlen, könnyen megfigyelhető mutatószám segítségével. ${ }^{28}$

Jelen írásnak nem célja az árstabilitási cél és a pénzügyi stabilitási cél viszonyrendszerének részletes tárgyalása. Azt azonban érdemes megjegyezni, hogy az esetek jelentős részében makroprudenciális eszközök kamatpolitikai támogatás nélkül is alkalmasak pénzügyi stabilitási feszültségek kezelésére, az árstabilitási szempontok alapján hozott kamatdöntések pedig segíthetik a pénzügyi stabilitás megőrzését (a kamatpolitika is egy makroprudenciális eszköz). Buborékok formálódása ellen a monetáris szigorítás hatásos fegyver lehet gyorsuló infláció esetén. Skizofrén helyzetbe kerül a jegybank azonban abban a hipotetikus esetben, amikor pénzügyi stabilitási szempontból a monetáris feltételek szigorítása, árstabilitási szempontból pedig a kondíciók lazítása volna indokolt. Nyilvánvaló a választás, ha a pénzügyi összeomlás vagy az inflációs cél elvétése a döntési alternatíva.

A lassan felépülő stabilitási kockázatokra azonban nem a stabilitást erősítő és az árstabilitást gyengítő döntések jelentik a jó választ. Ekkor a jegybank magatartása az lehet, hogy a makroprudenciális eszköztár egyéb elemeit használja, és csak akkor tesz a kamatpolitika logikájával nem konzisztens lépést a stabilitás védelmében, ha a makroprudenciális eszközök használatának lehetőségei kimerültek, és a folyamatok folytatódása belátható időn belül a pénzügyi stabilitás elvesztéséhez vezet. Ebben a végső esetben a pénzügyi stabilitásnak kell elsőbbséget élveznie az árstabilitással szemben. Addig, amíg más eszközökkel is fenntartható a pénzügyi stabilitás, változatlanul az árstabilitás a jegybank elsődleges célja. Jelenleg a legtöbb helyen nincs érdemi konfliktus a jegybank feladatai között: az inflációs kilátások egyre több országban kamatemelést indokolnak, nincs azonban arra utaló jel, hogy a magasabb kamatszint gyengítené a pénzügyi stabilitást.

\footnotetext{
${ }^{28}$ Ebből következően a jegybank pénzügyi stabilitással kapcsolatos elszámoltathatóságának kritériumrendszere is meglehetősen bizonytalan lábakon áll, és könnyen válik politikai csatározások forrásává.
} 
A jegybanknak kell makroprudenciális tevékenységet végeznie, de ez a tevékenység nem lehet a kormánytól független. ${ }^{29}$ Egyrészt, a makroprudenciális politika nem a jegybank privilégiuma, ennek a politikának a kormányzat is alakítója, így a döntések csak a kormányzattal együttmüködésben születhetnek meg. A túlzott hitelezési dinamika visszafogására állami kamattámogatás, állami garanciavállalási szabályok módosítása, a megkövetelt fedezetekkel, banki tőkekövetelményekkel kapcsolatos elöírások módosítása és kamatpolitikai döntések egyaránt szóba kerülhetnek. A legészszerübb döntés megtalálása pénzügyminisztériumi, bankfelügyeleti és jegybanki megfontolások együttes figyelembevételét feltételezi.

Másrészt, a makroprudenciális döntések gyakran konkrét ágazatokat, jövedelemtulajdonosok meghatározott csoportjait érintik, és ezáltal a klasszikus monetáris politikai döntéseknél nagyobb és közvetlenebb a hatásuk az elosztásra (De HaanEijffinger [2016]). Nyilvánvalóan nem volna kívánatos, ha a jegybank kormányzati beleszólás nélkül, a pénzügyi stabilitás szempontjaira hivatkozva, önállóan módosíthatná például a lakáspolitikával kapcsolatos szabályokat, ideértve a kilakoltatással kapcsolatos rendelkezéseket is. A legnagyobb eséllyel akkor lehet mentesíteni a makroprudenciális tevékenységet a napi politika kiszolgálásától, ha e politika fö felelöse egy nem politikai ciklusok által vezérelt intézmény. Politikusok kisebb erővel lépnek fel egy állami kedvezményekkel támogatott lakáshitelezési boom ellen, ha reménykedhetnek a sok elégedett lakástulajdonos támogató szavazataiban. Ez pedig a jegybank vezető szerepét indokolja. A jegybank rendelkezésére álló elemzési szaktudás, valamint a monetáris politikai és - esetleg - bankfelügyeleti szakterületről származó információk szintén ezt indokolják. A monetáris politika és a makroprudenciális politika közötti feszültségeket is azzal lehet a minimálisra szorítani, ha a jegybank az utóbbiban vezető szerepet játszik.

Miközben a kamatpolitika területén változatlanul szükséges a jegybanki függetlenség megőrzése, addig a makroprudenciális feladatok a kormányzattal való szoros együttműködést igénylik. E szerepek külön-külön jól megalapozottak, de együttes gyakorlásuk zavarok forrása lehet. A kamatpolitika és a makroprudenciális politika közötti választóvonal a kölcsönhatások következtében elmosódott. A közvélemény és a politikusok számára pedig különösen nehéz a jegybankban az egyik szempontból együttműködő partnert, a másikból pedig önállóságát kényesen óvó intézményt látni. Részben ugyanazok a személyek a kamatpolitika és a makroprudenciális politika alakítói is. Ök egyik minőségükben független döntéshozók, a másikban kooperációs partnerek. Minthogy a kormányzat a jegybankkal együtt alakítója a makroprudenciális politikának, képviselöi könnyen érezhetnek késztetést a monetáris politika befolyásolására is. A makroprudenciális politika döntései érdekviszonyokat érintenek, lobbicsoportokat aktivizálnak, a csoportok politikai képviseletet kapnak, és ezáltal

\footnotetext{
${ }^{29}$ A nemzetközi irodalomban ez a többségi vélemény (lásd például Kohn [2014], Cecchetti [2013], Balls és szerzőtársai [2016]). Ueda-Valencia [2012] szerint azonban a társadalmi optimum nem érhető el, ha a jegybank egyszerre végez monetáris politikai és makroprudenciális feladatokat. Az optimumhoz szerintük az sem elegendő, ha a jegybank független, de a makroprudenciális szabályozó nem az. Felfogásunk szerint az optimum elérésének a feltétele a jegybank és a makroprudenciális szabályozásért felelős intézmény egyidejűleg fennálló politikai függetlensége.
} 
a jegybank - a makroprudenciális politika egyik alakítójaként - a politikai küzdelmek terepén találja magát. A politikai nyomás viszont aligha áll meg a makroprudenciális ügyek határán, az a valószínű, hogy átgyürüzik a monetáris politikára is.

A függetlenség és kooperáció kettőssége mellett a de jure és de facto megkülönböztetés a korábbinál is indokoltabb. Az árstabilitás szempontjából a jegybank eszközfüggetlensége az optimális intézményi forma. A jegybank tevékenységének a korábbinál nagyobb átpolitizáltsága és - ennek folyományaként - a politikai nyomásgyakorlásnak való nagyobb kitettsége következtében azonban a monetáris politika területén is beszükülhet a jegybankok függetlensége. De jure értelemben is zajlanak kísérletek a függetlenség korlátozására, leginkább azonban a formális keretek változtatása nélkül, de facto értelemben - a válság előtti időszakhoz képest - szorul szükebb keretek közé a jegybankok függetlensége. Ez nem okoz közvetlen károkat a jelenlegi alacsony inflációs környezetben. A társadalom számára a negatív következmények akkor merülnek fel, amikor - az árstabilitás érdekében - szigorító monetáris politika válik szükségessé, azonban a jegybanknak esetleg nincs ereje a rövid távú politikusi érdekektöl eltérő döntések meghozatalához.

\section{Következtetések}

A pénzügyi válság előtti időszakban szinte általános egyetértés volt abban, hogy a jegybanki függetlenség az árstabilitás elérésének szükséges feltétele. A függetlenség a jegybanki mandátum és a monetáris politika alapvető céljai érdekében alkalmazott eszközök rövid távú, politikai érdekek befolyásától mentes használatát jelentette. A jegybankok feletti társadalmi ellenőrzést a jegybankok elszámoltatásának fórumai, valamint a jegybanki célok törvényi meghatározása biztosította.

A 2000-es évek elejére a legtöbb országban de jure értelemben magas szintű függetlenséget élveztek a jegybankok. A jegybanki döntéshozók kinevezése (és felmentése) során érvényesülő politikai szempontok, valamint a monetáris politikai döntéshozatalra nehezülő politikai nyomás következtében azonban a jegybankok tényleges függetlensége érdemlegesen kisebb volt annál, mint amit a formális függetlenségindexek jeleztek. Látszatfüggetlenségről lehet szó akkor, ha egy jegybank élére kormányzati politikai érdekeket kiszolgáló volt kormányzati politikus vagy egy lojális hivatalnok kerül.

A pénzügyi válságot követően a jegybanki függetlenséget megalapozó elvi megfontolások érvényessége átmenetileg meggyengült. Sem az infláció - árstabilitás elérését szolgáló - növelése, sem a költségvetés mozgásterének bővítése érdekében szükségessé vált költségvetési finanszírozás nem igényelte a jegybank függetlenségét. A makrogazdasági helyzet jövőbeli normalizálódásával azonban ezek a megfontolások nem veszítették el érvényességüket.

A monetáris politikai célok a válság utáni időszakban is a jegybank függetlensége mellett teljesíthetők a legnagyobb biztonsággal. A válságot követően a jegybankok feladatköre kibővült a pénzügyi stabilitás védelmével. A makroprudenciális tevékenységet azonban csak a kormányzattal együttmüködésben lehet végezni. Ezen a 
területen nem lehetséges jegybanki függetlenség. A két cél és a két müködési forma csak nagy nehézségekkel hangolható össze. A kormányzattal kooperációban végzett makroprudenciális tevékenységgel egyidejüleg nehéz megőrizni a monetáris politika függetlenségét. A de facto értelemben beszükülő jegybanki függetlenség negatív társadalmi következményei akkor válnak láthatóvá, amikor - a jövőben - az árstabilitás érdekében szigorító monetáris politika válik szükségessé, ám a rövid távú politikusi érdekektől esetleg eltérő döntések meghozatalához nincs ereje a jegybanknak.

\section{Hivatkozások}

Alesina, A. [1988]: Macroeconomics and Politics. NBER Macroeconomics Annual, 3. https:// doi.org/10.2307/3584936.

Arnone, M.-Laurens, B.-Segalotto, J.-F.-Sommer, M. [2007]: Central Bank Autonomy: Lessons from Global Trends. IMF Working Paper, WP/07/88.

Arnone, M.-Romelli, D. [2013]: Independence Indices and Inflation Rate: A New Empirical Exploration. Journal of Financial Stability, Vol. 9. No. 3. 385-398. o. https://doi. org/10.1016/j.jfs.2013.03.002.

Balls, E.-Howat, J.-Stansbury, A. [2016]: Central Bank Independence Revisited: After the financial crisis, what should a model central bank look like? Mossavar-Rahmani Center for Business and Government, Working Paper, Series No. 67.

Bernanke, B. S. [2005]: Inflation in Latin America: A New Era? At the Stanford Institute for Economic Policy Research Economic Summit, Stanford, California, február 11. https:// www.federalreserve.gov/boarddocs/speeches/2005/20050211/default.htm.

BernANKE, B. S. [2010]: Central Bank Independence, Transparency, and Accountability. Előadás, https://www.federalreserve.gov/newsevents/speech/bernanke20100525a.htm.

Bernanke, B. S. [2016]: "Audit the Fed" is not about auditing the Fed. Blogbejegyzés, 2016. január 11. https://www.brookings.edu/blog/ben-bernanke/2016/01/11/audit-the-fed-isnot-about-auditing-the-fed.

Bernhard, W. [1998]: A Political Explanation of Variations in Central Bank Independence. American Political Science Review, Vol. 92. No. 2. 311-327. o. https://doi.org/10. 2307/2585666.

Bossone, B. [2015]: Macroeconomic policy coordination and central bank independence after the crisis. Blogbejegyzés, augusztus 3. http://blogs.worldbank.org/allaboutfinance/ macroeconomic-policy-coordination-and-central-bank-independence-after-crisis- 0 .

CARgILl, T. [1995]: The Statistical Association between Central Bank Independence and Inflation. Banco Nazionale del Lavoro Quarterly Review, 193. 159-172. o.

Cargill, T. [2016]: The Myth of Central Bank Independence. Mercatus Working Paper. Mercatus Center at George Mason University, Arlington, VA, https://www.mercatus.org/ system/files/mercatus-cargill-central-bank-vl.pdf.

Cecchetti, S. [2013]: Central bank independence: A path less clear. Remarks prepared for the International Conference held to commemorate the 20th anniversary of the autonomy of the Bank of Mexico, Mexico City, október 14. http://people.brandeis.edu/ cecchett/ BISSp/BISSp17.pdf.

Crowe, C.-Meade, E. [2007]: The Evolution of Central Bank Governance around the World. Journal of Economic Perspectives, Vol. 21. No. 4. 69-90. o. https://doi.org/10.1257/ jep.21.4.69. 
Cukierman, A. [1992]: Central Bank Strategy, Credibility, and Independence: Theory and Evidence. MIT Press, Cambridge, MA.

Cukierman, A.-Web, S.-Neyapti, B. [1992]: Measuring the Independence of Central Banks and Its Effect on Policy Outcomes. World Bank Economic Review, Vol. 6. No. 3. 353-398. o. https://doi.org/10.1093/wber/6.3.353.

De HaAn, J.-Eijffinger, S. [2016]: The politics of central bank independence. De Nederlandsche Bank Working Paper, No. 539. https://www.dnb.nl/en/binaries/Working\%20 paper\%20539_tcm47-350814.pdf.

Debelle, G.-Fisher, S. [1994]: How Independent Should a Central Bank Be? Megjelent: Goals, Guidelines, and Constraints Facing Monetary Policy Makers. Federal Reserve Bank of Boston Conference, Series No. 38.

Dincer, N.-Eichengreen, B. [2014]: Central Bank Transparency and Independence: Updates and New Measures International. Journal of Central Banking, Vol. 10. No. 1. 189-259. o. https://doi.org/10.2202/1565-3404.1237.

Eijffinger, S.-van Keulen, M. [1995]: Central Bank Independence in Another Eleven Countries. Banco Nazionale del Lavoro Quarterly Review, 192. 39-83. o.

Ennser-Jedenastik, L. [2013]: Party Politics and the Survival of Central Bank Governors. European Journal of Political Research, Vol. 53. No. 3. 500-519. o. https://doi. org/10.1111/1475-6765.12045.

FisCHER, S. [2016]: Central Bank Independence. Herbert Stein-emlékelőadás. National Economists Club, Washington, D. C., november 4. https://www.federalreserve.gov/newsevents/ speech/fischer20151104a.htm.

Grilli, V.-Masciandaro, D.-Tabellini, G. [1991]: Political and monetary institutions and public financial policies in the industrial countries. Economic Policy, Vol. 13. No. 6. 341392. o. https://doi.org/10.2307/1344630.

Hallerberg, M. [2002]: Veto Players and the Choice of Monetary Institutions. International Organization, Vol. 56. No. 6. 775-802. o. https://doi.org/10.1162/002081802760403775.

Havrilesky, T. [1993]: The Pressures on American Monetary Policy. Kluwer Academic Publishers, Boston, https://doi.org/10.1007/978-1-4757-2228-4.

Hayo, B. [1998]: Inflation culture, central bank independence and price stability. European Journal of Political Economy, Vol. 14. No. 241-263. o. https://doi.org/10.1016/s01762680(98)00006-8.

Hayo, B.-Hefeker, C. [2001]: Do We Really Need Central Bank Independence? A Critical Re-examination. University of Basel, WWZ Working Paper, No. 01/03. https://doi. org/10.2139/ssrn.264454.

Kydland, F.-Prescott, E. [1977]: Rules Rather than Discretion: The Inconsistency of Optimal Plans. Journal of Political Economy, Vol. 85. No. 3. 473-491. o. https://doi. org/10.1086/260580.

Koнn, D. [2014]: Federal Reserve Independence in the Aftermath of the Financial Crisis: Should We Be Worried? Business Economics, Vol. 48. No. 2. 104-107. o. https://doi. org/10.1057/be.2013.1.

Lynn, M. [2012]: The era of central bank independence is over. Market Watch, december 5. http://www.marketwatch.com/story/the-era-of-central-bank-independence-is-over2012-12-05.

Mangano, G. [1998]: Measuring central bank independence: A tale of subjectivity and of its consequences. Oxford Economic Papers, Vol. 50. No. 3. 468-492. o. https://doi.org/10.1093/ oxfordjournals.oep.a028657. 
Masciandaro, D.-Romelli, D. [2017]: The evolution of central bank independence and inflation: Causal evidence from dynamic indices. Conference Paper, Vancouver.

Mishrin, F. [2007]: Monetary Policy Strategy. MIT Press, Cambridge, MA.

Mishinin, F. [2011]: Monetary Policy Strategy: Lessons from the Crisis. NBER Working Paper Series, National Bureau of Economic Research, Working Paper, 16755. https://doi. org/10.3386/w16755.

Nordhaus, W. [1975]: The Political Business Cycle. Review of Economic Studies, Vol. 42. No. 2. 169-190. o. https://doi.org/10.2307/2296528.

Pisha, A. [2011]: Eurozone indices: A new model for measuring central bank independence. Special Conference Paper, 5. Bank of Greece, Athen, http://www.bankofgreece.gr/Bog Ekdoseis/SCP201105.pdf.

Posen, A. [1993]: Why Central Bank Independence Does Not Cause Low Inflation: There is No Institutional Fix for Politics. Megjelent: O’Brien, R. (szerk.): Finance and the international economy: In memory of Robert Marjolin. Oxford University Press, Oxford, 40-65. o.

Posen, A. [1995]: Declarations Are Not Enough: Financial Sector Sources of Central Bank Independence. NBER Macroeconomics Annual, 10. https://doi.org/10.1086/654279.

Rogoff, K. [1985]: The Optimal Degree of Commitment to an Intermediate. Quarterly Journal of Economics, Vol. 100. No. 4. 1169-1189. o. https://doi.org/10.2307/1885679.

Sargent, T. J.-Wallace, N. [1981]: Some Unpleasant Monetarist. Federal Reserve Bank of Minneapolis Quarterly Review, Vol. 5. No. 3. 1-17. o.

SAntoni, G. [1986]: The effects of Inflation on Commercial Banks. Federal Reserve Bank of St. Louis Review, március, 15-26. o.

Stiglitz, J. [1998]: Central Banking in a Democratic Society. De Economist, Vol. 146. No. 2. 199-226. o. https://doi.org/10.1023/a:1003272907007.

Stiglitz, J. [2013]: A Revolution in Monetary Policy: Lessons in the Wake of the Global Financial Crisis. 15. C. D. Deshmukh-emlékelőadás, Mumbai, január 3. https://rbidocs. rbi.org.in/rdocs/Speeches/PDFs/PSS030113FL.pdf.

Summers, L. H. [2016]: Secular Stagnation and Macroeconomic Policy. Mundell-Fleming Lecture, International Monetary Fund, november 3.

Turner, A. [2015]: The Case for Monetary Finance - An Essentially Political Issue 16th Jacques Polak Annual Research Conference, Washington, D. C., november 5-6. International Monetary Fund, https://www.imf.org/external/np/res/seminars/2015/arc/pdf/adair.pdf.

Ueda, K.-VAlencia, F. [2012]: Central Bank Independence and Macro-prudential Regulation. IMF Working Paper, 2012/101. http://dx.doi.org/10.5089/9781475502916.001.

VAsile, P. [2013]: The independence of central banks in central and eastern Europe: A monetary policy strategy based approach. Annals of the Constantin Brâncuşi University of Târgu Jiu, Economy Series No. 3.

Vuletin, G.-Zhu, L. [2011]: Replacing a “Disobedient" Central Bank Governor with a "Docile” One: A Novel Measure of Central Bank Independence and Its Effect on Inflation. Journal of Money, Credit and Banking, Vol. 43. No. 6. 1185-1215. o. https://doi.org/10.1111/j.15384616.2011.00422.x. 